\title{
The role of robots in the improving work of nurses
}

Rola robotów w usprawnieniu pracy pielęgniarek

\section{Łukasz Blecharr , , Patrycja Zalewska²}

\author{
${ }^{1}$ Maria Curie-Skłodowska University, Faculty of Philosophy and Sociology, Department of Logic and Cognitive Science/ \\ Wydział Filozofii i Socjologii, Zakład Logiki i Kognitywistyki, UMCS w Lublinie \\ ${ }^{2}$ Maria Curie-Skłodowska University, Faculty of Philosophy and Sociology, Department of Sociology of Medicine and Family/ \\ Wydział Filozofii i Socjologii, Zakład Socjologii Zdrowia, Medycyny i Rodziny, UMCS w Lublinie
}

\section{STRESZCZENIE}

Słowa kluczowe:

ABSTRACT

Key words:

\section{ROLA ROBOTÓW W USPRAWNIENIU PRACY PIELĘGNIAREK}

Wprowadzenie. Współcześnie obserwujemy postępującą zmianę rynku pracy przez nowe osiągnięcia w zakresie technologii powiązanych ze Sztuczną Inteligencją.

Cel. Pragniemy przedstawić obecne trendy wpływające na pracę pielęgniarek oraz położnych na całym świecie, by zwiększyć świadomość społeczną na temat zachodzących zmian wśród pracowników polskiej ochrony zdrowia. Zwracamy tutaj uwagę na fakt konieczności zaangażowania samych zainteresowanych w trwające dyskusje i projekty badawcze, by możliwie dobrze zrozumieć ich potrzeby i oczekiwania.

Dyskusja. W ramach artykułu przytaczana jest obecna sytuacja technologiczna. Rozpoczynamy opracowanie nakreśleniem ram percypowanych zmian w strukturze i zadaniach pielęgniarek na świecie. Następnie przytoczone zostają kolejne przykłady robotów je realizujących. Począwszy od eliminowania prostych, rutynowych czynności przez takie produkty jak TUG czy HOMER, przechodzimy przez możliwe rozwiązania do wyeliminowania konieczności osobistego wykonywania zabiegów inwazyjnych (jak za pomocą BloodBota) oraz nieinwazyjnych (CLARA), aż po przedstawienie maszyn wykorzystywanych w terapii zastępującej zwierzęcą, mającą zwłaszcza zastosowanie w kontakcie z pacjentami wykazującymi się utrudnioną komunikacją.

Wnioski. Pragniemy przedstawić przyszłość pielęgniarstwa ściśle powiązaną z maszynami. Przy czym pragniemy wyeksponować pierwiastek komplementarności tej relacji i fakt, że wykonywanie części zadań przez roboty nie wiąże się z zastępowaniem ludzi, lecz raczej z umożliwieniem im przeniesienia skupienia z wykonywania żmudnych obowiązków do zwiększonego czasu na empatyczną pracę z pacjentem.

pielęgniarki, sztuczna inteligencja , opieka nad pacjentem, efektywność wykonywania zadań i ich analiza, robotyka

\section{THE ROLE OF ROBOTS IN THE IMPROVING WORK OF NURSES}

Introduction. Currently we observe a change in the labor market. It is caused by the new developments in the field of artificial Intelligence.

Aim. We would like to present current trends affecting the work of nurses and midwives around the world in order to raise the social awareness of these changes among Polish healthcare workers. Moreover, we want to emphasize the fact that it is necessary to involve them as the stakeholders in the ongoing discussions and research projects in order to better understand their needs and expectations. Discussion. The article revolves around the current state of technology. We begin by outlining the framework of the perceived changes in the nurses' structures and tasks around the world. Then we provide the examples of a variety of robots already executing those tasks. We start with the robots whose purpose is the elimination of simple, routine activities such as TUG or HOMER. After doing so, we move on to possible solutions how to eliminate the need for personal involvement in invasive (such as BloodBot) and non-invasive procedures (CLARA). We finish by introducing the machines used to replicate animal therapy, which can be used to treat patients who have difficulties with communicating their needs.

Conclusions. We would like to present the future of nursing closely related to machines. We want to emphasize the element of complementarity of this relation and the fact that performing some tasks by robots is not connected with replacing people, but rather with enabling them to shift their focus from the performance of arduous duties to spending more time on empathic work with the patient.

nurses, artificial intelligence, patient care, effectiveness and analysis of tasks, robotics 


\section{INTRODUCTION}

We are currently witnessing far-reaching changes in the labor market. Thanks to technological achievements we are able to notice and record the surrounding processes better and better, what in turn allows us to improve our description of them and, ultimately, improve them. This progress in optimizing work also applies to the profession of nurse ${ }^{1}$. Thanks to modern solutions we are able to relieve people currently working in similar positions, increase their efficiency and job satisfaction.

However, paradoxically, the voice of nurses is not as often taken into account in the design of these solutions as it could be. This is due to a lack of understanding of the possibilities offered by technology. In this article we wish to signal the need to speak out in ongoing discussions and to engage in clarifying the needs of how the work of a nurse can be improved. Ultimately, as Richard Booth, Assistant Professor at the Arthur Labatt Family School of Nursing in London, said, "If we don't mediate this technology, someone will do it for us", and continues, "We have to plan our own obsolescence to some extent because some predictable nursing work and activities that aren't extremely complex will be automated" [1].

\section{Automation of routine tasks}

Automation is a process in which we classify repetitive tasks into procedures. It should be assumed that robots are not able to replace man in all tasks related to nursing. This does not mean, however, that they are not able to support him in his activities and speed up the nurturing processes.

Nurses very often perform monotonous activities, such as delivering meals, distributing medicines or collecting blood $[2,3]$. The machines are able to help the nurses in performing these activities.

An example of a machine that can support a person in such tasks is a robot called TUG, a product of the American company Aethon. It moves using lasers to detect and avoid obstacles. Reflecting the laser from the environment, the TUG is able to build a three-dimensional map, which it uses to complement the previously uploaded traditional hospital map. It easily moves to other floors, thanks to the possibility of summoning the lift. Despite this smooth movement, the TUG robot sometimes needs help, e.g. when a trolley blocks a leg [3].

The TUG robot will help you with tasks such as: removing meal trays, delivering drugs on schedule and prescription, delivering patient cards, logistical support for the laboratory or blood bank, or delivering bed linen to the laundry [4,5]. At Royal Melbourne Hospital (Australia), TUG is used to deliver sterile instruments from sterilization to operating theatres [6].

${ }^{1}$ Speaking of technological advances in nursing, we must not forget about midwives. The professions of midwife and nurse are independent and the technologies listed below also apply to the profession of midwife. Due to the fact that in the literature on a given issue, specialists more often use the term "nursing" or "nurse", the authors of this text will also use such a nomenclature.
Another example is the HOMER robot, also the Aethon's product. This machine helps to manage hospital equipment such as wheelchairs, pumps, monitors, respirators, beds, etc. The HOMER robot identifies objects by reading RFID tags and in the meantime the TUG robot moves the equipment to where it is needed or puts it back in its place [4].

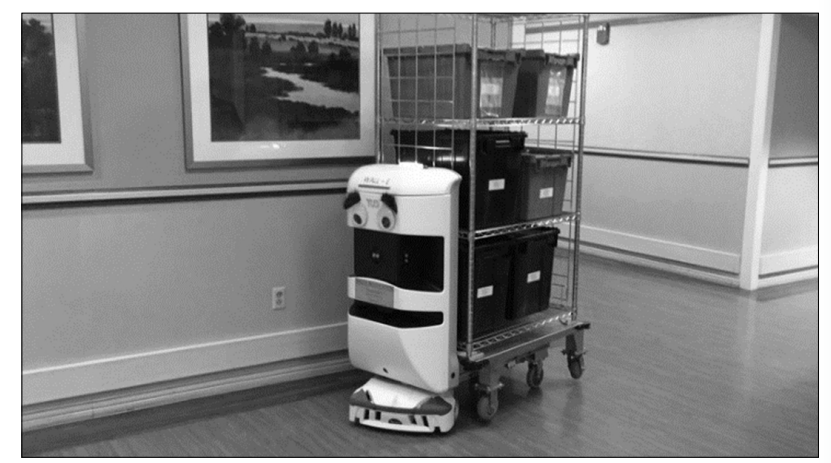

Fig 1. TUG robot

Source: https://www.businesswire.com/news/home/20150519005310/en/ St.-Elizabeth-Healthcare-Enters-Robotic-Age-TUG /dostęp 12.07.2019/

Another example of a robot used for menial tasks is the SpeciMinder robot by CCS Robotics. He collects samples for laboratory tests in the rooms and delivers them to the laboratory. Like the TUG robot, it uses the building map for navigation and cooperates with the user. It has security features in the form of a card reader to prevent unauthorized access to samples. The SpeciMinder robot recognizes the battery charge status itself. When the battery is low, it drives up to a special docking station and charges the batteries $[7,8,9]$.

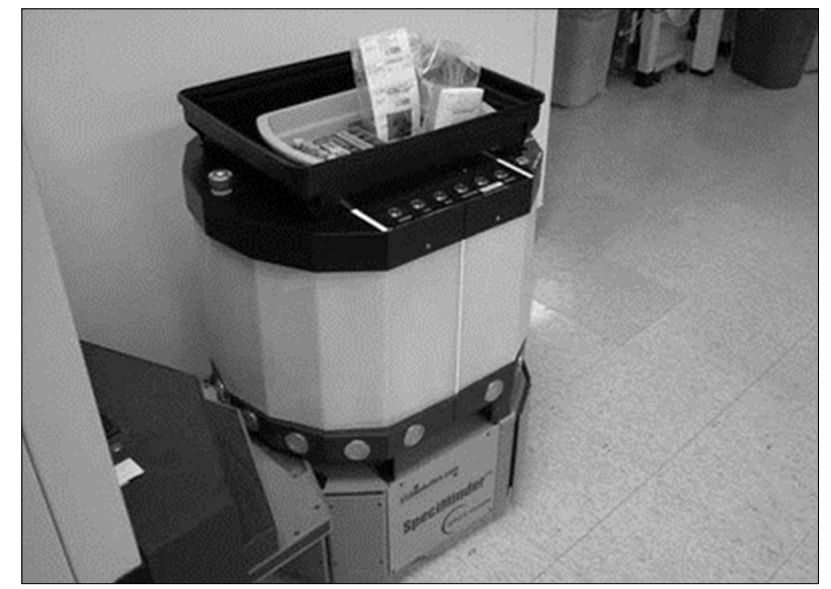

Fig 2. SpeciMinder Robot

Source: http://www.ccsrobotics.com/products/speciminder.html /dostęp 12.07.2019/

\section{Use of robots to perform invasive activities}

Another example of using modern technologies to automate tasks is the Bloodbot robot. It was created by Alex Zivanovic of Imperial College in London. It is able to autonomously search for blood vessels and make punctures with an accuracy of $1 \mathrm{~mm}$. It is worth noting that it is able to distinguish between muscles, fat tissue and, above all, blood vessels. In addition, the Bloodbot robot is equipped with a system to prevent through-passing. It has a force 
sensor which determines the moment of insertion of the needle into the vein - the maximum resistance is then set and then the pressure is quickly reduced - the needle is in the blood vessel. If the pressure drops, the machine immediately stops the further movement of the needle. Bloodbot, apart from collecting blood for tests, can also perform intravenous injection [10].

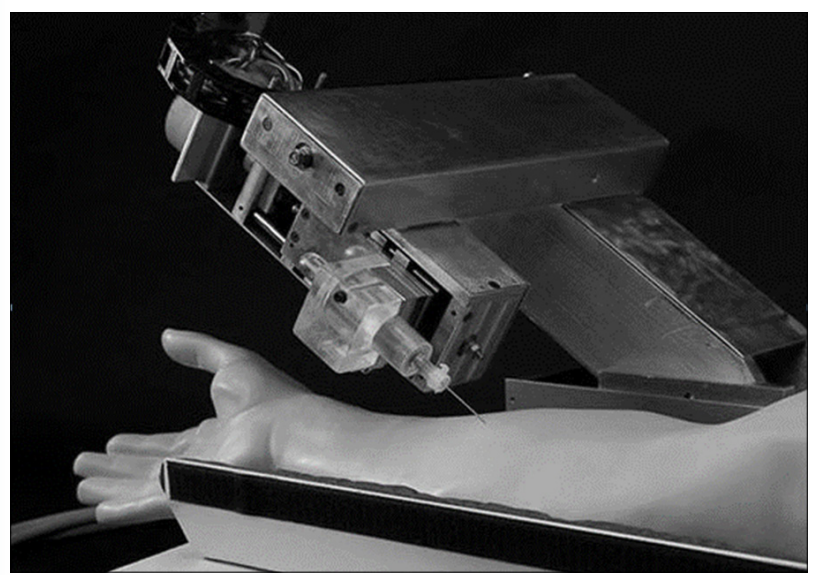

Fig 3. Bloodbot robot

Source: http://www.asimo.pl/modele/bloodbot.php /dostęp 12.07.2019/

A vein scanner (non-contact vascular/vascular illuminator) is also an aid to the blood collection process. A vein scanner can be useful when inserting a peripheral intravenous catheter (PIVC) or when collecting blood from the so-called difficult patients, such as newborns, elderly patients, obese patients, patients with skin diseases or dark complexion. To put it simply, it is a portable device $(<500 \mathrm{~g})$ for locating veins. The vein scanner works on the principle of emitting infrared light and invisible laser radiation, which is used to detect veins and highlight their position on the skin. This effect is achieved by absorption of infrared radiation by hemoglobin in the blood $[11,12]$.

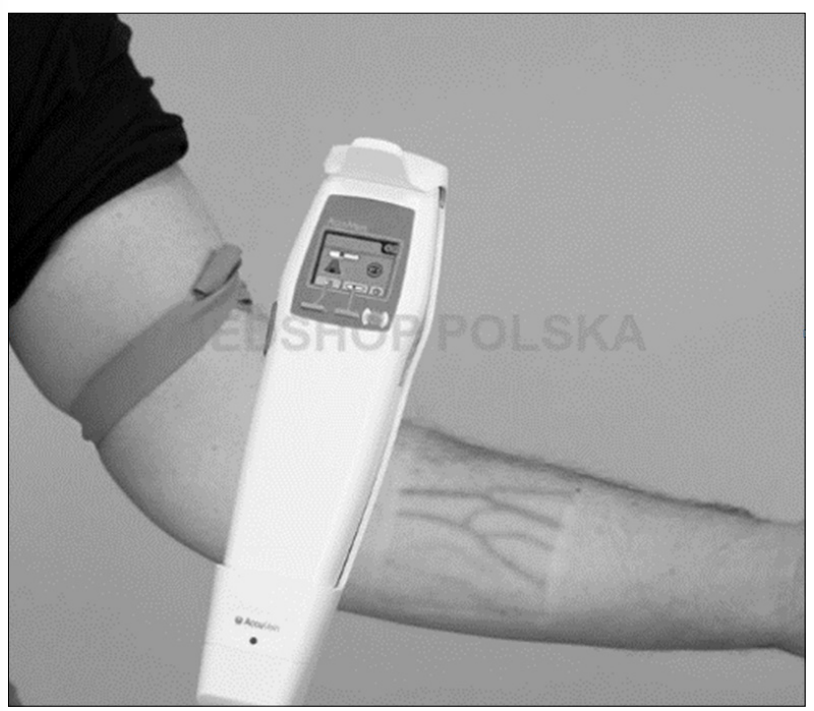

Fig 4. Non-contact AccuVein AV400 Vascular Illuminator Venous Scanner

https://medshop.pl/bezkontaktowy-iluminator-naczyniowy-accuvein-av400.html /dostęp z dnia 13.07.2019/

\section{Clara's „Nurse" as an example of a robot performing non-invasive activities}

Mechatronic nurse Clara is constructed by scientists from USC Interaction Lab. This robot was named after Clara Barton, the founder of the American Red Cross. Clara robot moves along pre-determined routes between patients' beds, but is able to detect and avoid obstacles. Clara is an assistant to the nursing staff. Ultimately, its task is to assist nurses in simple diagnostic activities such as: blood pressure measurement or spirometry tests. It identifies patients by scanning the code placed on their beds. The Clara Robot has a screen that displays instructions on how to exercise. It can communicate with patients by giving affirmative or negative answers for the questions. Aizu Central Hospital (Japan) has two such robots. One of them works in the registration office, where he answers patients' questions, while the other one takes the patients to the appropriate room and carries their luggage [13].

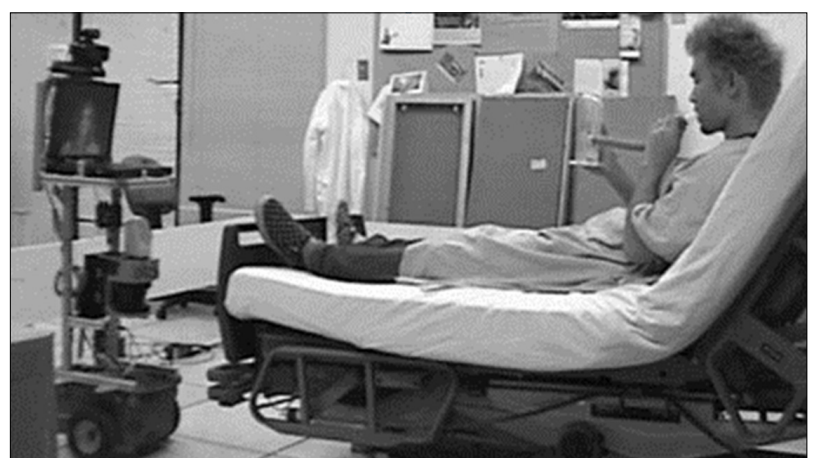

- Fig 5. Clara Robot

Source: http://www.asimo.pl/modele/clara.php /dostęp 12.07.2019/

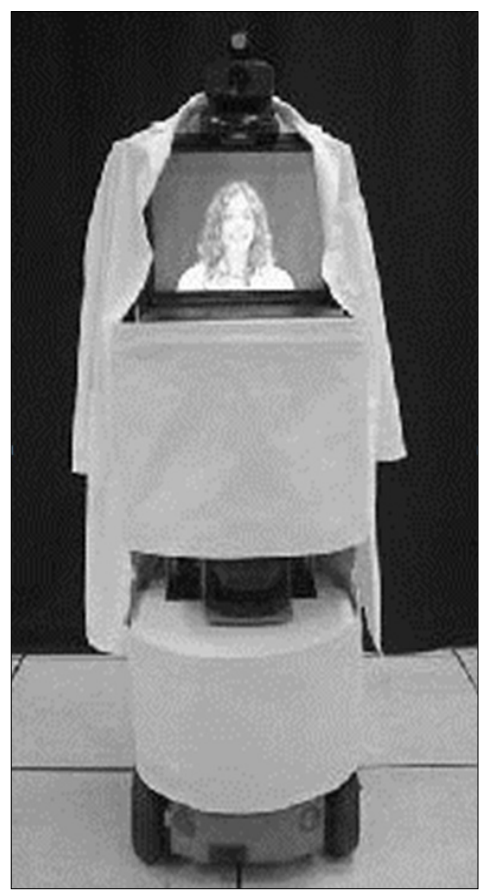

Fig 6. Clara Robot

Source: http://www.asimo.pl/modele/clara.php /dostęp 12.07.2019/ 


\section{Fluffy seal - robotic animal therapy}

Previous applications have been used by nurses in routine, often tedious and repetitive tasks. However, this does not exhaust the scope of assistance offered by technological solutions. Another group of robots are the so-called mental robots. Their main role is to produce desired psychological effects such as pleasure or relaxation, and their basic „medium” is non-verbal communication. An important research branch here is the transfer of the effects of animal therapy to safer, universal and applicable measures for as many patients as possible. It has been noticed that animal therapy brings improvement in three areas: psychological (relaxation), physiological (reduction of stress level, improvement of vital parameters) and social (stimulation of communication between patients and caregivers). However, it should be noted that animal therapy is not always possible - for such reasons as bacteria transmitted by animals, the risk of scratches or allergic reactions.

Considering the measurable benefits of animal therapy, it was decided to create an interactive robot-animal. At the stage of designing such a robot three categories were assumed: familiar animals (e.g. a dog, a cat), unknown animals (e.g. a seal) and invented/abstracted animals. Developed prototypes were presented to the research. The differences perceived by the subjects in contact with familiar animals were problematic - for example, cats were too soft and not natural enough $[14,15,16]$. Conceived animals, on the other hand, did not activate the subjects in the desired way. Seals turned out to be a compromise, as the participants did not have extensive knowledge about the behavior and habits of seals, so they were not able to compare the robot with the animal. The research was carried out in seven countries: Japan, Great Britain, Italy, Sweden, Korea, USA and Brunei, which suggests that the seal robot can be universally accepted despite cultural and religious differences $[15,16,17]$.

Paro robot was designed for therapy. It is an almost three-kilogram $(2.7 \mathrm{~kg}$ ) seal, measuring $57 \mathrm{~cm}$. It has 340 sensors and 5 sensors: hearing, touch, light, temperature and posture, as well as antibacterial, dirt-resistant hair that does not fall out [18]. It is equipped with an electromagnetic plate in order not to affect patients with pacemakers $[14,15]$. The Paro robot is interaction-oriented, picking up the presence of a human being in the vicinity, thanks to the presence of sensors. Then he starts to move, squeak, he demands to be stroked. It reacts to activities, i.e.: it can blink during stroking and then it purrs, on the other hand it screams when beaten. It can tip its head towards the direction from which the sound is coming. The nature of a Paro robot can change depending on the way it is treated: when it is often beaten, it becomes antisocial and squeaks during stroking. Conversely, when treated well, it is social and friendly $[14,15,19]$.

The Paro robot has a positive impact on elderly people, demented patients who have significantly reduced their ability to communicate, on the children in paediatric wards and on people with disabilities. The seal forces interactions and enhances the protective instincts so much that patients begin to take care of it. It relaxes and simultaneously stimulates them, relieves emotional tension and makes them happy. Stroking soft fur causes endorphins, i.e. natural analgesics to be secreted and cortisol and noradrenaline levels to be lowered [18]. Denmark has introduced 1000 robots into its elderly care facilities [20]. In Poland, the first Paro seal moved into the Sopot Social Welfare Home $[14,21]$, followed by the next one in the Polish Association for Persons with Intellectual Disabilities in Skarszewy [22].

Anna Rzeczyńska, a therapist at the DPS (Social Welfare Home) in Sopot, recalls: „There was a lady here who no longer communicates with her surroundings in any way. She lived in her own world. When we started the seal therapy, she didn't say she didn't want to, she seemed agitated, so I gently put her seal on her knees. And then she started crying. And they weren't tears of sadness, but emotions, such as relief. As if something was moving in it, a fuse has been released" [18]. The Paro robot becomes a kind of mediator between the caregiver and the patient. It is a common theme and encourages communication [15].

Therapy with the use of animal robots is a growing area. Research has shown that the Paro Robot has enormous potential for mental care of the elderly. However, further research is needed in this area.

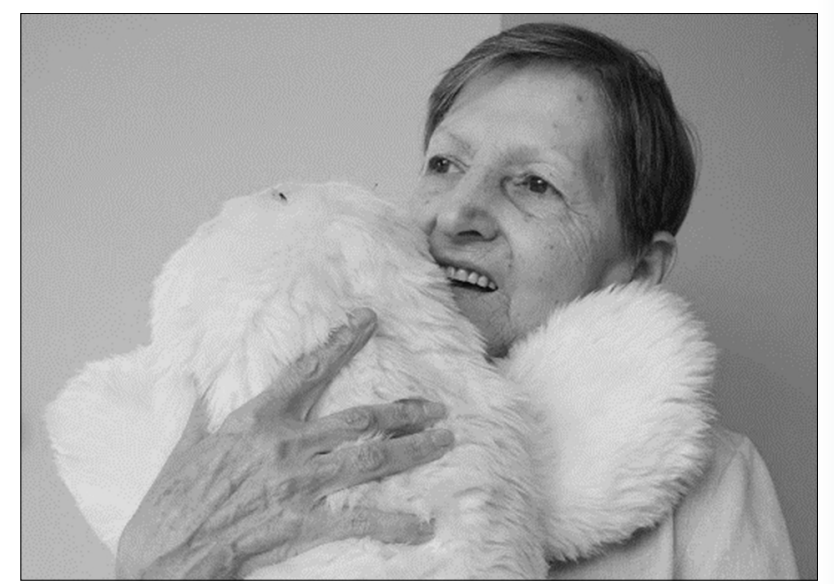

Fig 7. Paro robot

Source: https://www.sztucznainteligencja.org.pl/foka-alzheimera/ /dostęp 14.07.2019/

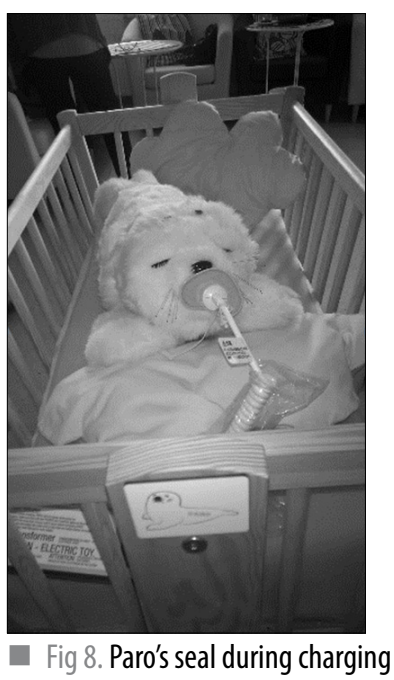

Source: https://www.facebook.com/pages/category/Health-Beauty/Foka-PARO-109892232722479//dostęp 12.07.2019/ 


\section{SUMMARY}

Being a nurse is a very demanding but also rewarding job that allows to touch the lives of many people. Empathy and care will never be replaced by technology. But innovation can free nurses from the burden of many monotonous and repetitive tasks [23].

In the context of contemporary nursing practice, such voices as J.A. Pepit's and R. Locsin's appear, who claim that nowadays the nursing process is often carried out in a highly repetitive manner, describe it as a „routine process". In their opinion, these routine tasks should be replaced by robots. Moreover, they believe that the profession of nurse can be threatened if a robot is built and marketed to imitate human movements, with artificial intelligence capable of making clinical decisions [24].
It is difficult to agree with such an approach, because a nurse needs to know the patient's bio-psycho-social condition before establishing the nursing process. Robots can facilitate or improve it, e.g. by measuring life parameters, but they cannot replace nurses who provide holistic care. It should be remembered that there is currently a significant shortage of nurses worldwide. The growing number of patients with a constant shortage of nurses leads to an increased number of infections or mortality of patients, faster professional burnout, lack of sufficient time to contact the patient. Robots are able to relieve the work of nurses in the most monotonous activities, saving time and energy that can be spent on contact with patient. Furthermore, it should be noted that the care system is by no means static and requires continuous improvement of processes. Ultimately, our aim is to improve health outcomes while keeping control of the increase in expenditure.

\section{Rola robotów w usprawnieniu pracy pielęgniarek}

\section{WSTĘP}

Obecnie obserwujemy daleko zachodzące zmiany w rynku pracy. Dzięki osiągnięciom technologicznym jesteśmy w stanie coraz lepiej dostrzec i zapisać otaczające nas procesy, a to z kolei pozwala nam je lepiej opisać by, ostatecznie, je usprawnić. Ten postęp w optymalizacji pracy dotyczy również zawodu pielęgniarki². Dzięki nowoczesnym rozwiązaniom jesteśmy w stanie odciążyć osoby obecnie pracujące na podobnych stanowiskach, zwiększyć ich efektywność oraz zadowolenie z pracy.

Jednakże, paradoksalnie, głos pielęgniarek nie jest tak często uwzględniany w projektowaniu tych rozwiązań jak mógłby być. Wynika to $\mathrm{z}$ braku zrozumienia możliwości oferowanych przez technologię. W ramach tego artykułu pragniemy zasygnalizować potrzebę zabrania głosu $\mathrm{w}$ toczących się dyskusjach oraz zaangażowanie w doprecyzowanie potrzeb usprawniania pracy pielegniarki. Ostatecznie, jak stwierdził Richard Booth, asystent-profesor przy Arthur Labatt Family School of Nursing w Londynie, ${ }_{2}$ Jeśli nie będziemy się wypowiadać na temat technologii, ktoś inny zrobi to za nas" (Org. "If we don't mediate this technology, someone will do it for us"), i kontynuuje „Musimy zaplanować własne, do pewnego stopnia, zastępowanie [przez maszynę], ponieważ część przewidywalnej pracy i zadań pielegniarskich, które nie sq skomplikowane zostana zautomatyzowane” (Org. "We have to plan our own

\footnotetext{
${ }^{2}$ Mówiąc o postępach technologicznych w pielęgniarstwie nie możemy zapomnieć o położnictwie. Zawód położnej, jak i pielęgniarki jest zawodem samodzielnym i wymienione niżej technologie dotyczą również zawodu położnej. Ze względu na fakt, iż w literaturze dotyczącej danego zagadnienia specjaliści używają częściej określenia „pielęgniarstwo” lub „pielęgniarka” autorzy niniejszego tekstu również zastosują takie nazewnictwo.
}

obsolescence to some extent because some predictable nursing work and activities that aren't extremely complex will be automated.").

\section{Automatyzacja rutynowych zadań}

Automatyzacja to proces w ramach którego klasyfikujemy powtarzalne zadania w procedury. Należy przyjąć, że roboty nie są w stanie zastąpić człowieka we wszystkich zadaniach związanych z pielęgniarstwem. Nie oznacza to jednak, że nie są w stanie wspomóc go w działaniach i przyspieszyć proces pielęgnowania.

Pielęgniarki bardzo często wykonują czynności monotonne, powtarzalne, takie jak dostarczanie posiłków, rozdawanie lekarstw czy pobieranie krwi $[2,3]$. W wykonywaniu wyżej wymienionych czynności maszyny są w stanie pielęgniarkom pomóc.

Przykładem maszyny, która jest w stanie wspomóc człowieka w takich zadaniach jest robot o nazwie TUG, produkt amerykańskiej firmy Aethon. Porusza się on używając laserów do wykrywania i omijania przeszkód. Odbijając laser od otoczenia TUG jest w stanie zbudować trójwymiarowa mapę, z której korzysta by uzupełnić wgraną uprzednio tradycyjną mapę szpitala. Bez problemu przemieszcza się na inne piętra, dzięki możliwości przywoływania windy. Mimo tak sprawnego poruszania się, robot TUG czasami potrzebuje pomocy np. w przypadku zablokowania nogi przez wózek [3].

Robot TUG pomoże podczas takich zadań, jak m.in.: usuwanie tac po posiłkach, dostarczanie leków zgodnie $\mathrm{z}$ harmonogramem i receptą, doręczanie karty pacjentów, obsługa logistyczna laboratorium lub banku krwi, czy dostarczanie bielizny pościelowej do pralni [4,5]. W Royal Melbourne Hospital (Australia) TUG jest wykorzystywany do rozwożenia sterylnych narzędzi ze sterylizacji na bloki operacyjne [6].

Kolejnym przykładem jest robot $H O M E R$, również firmy Aethon, dzięki któremu możliwe jest zarządzanie 
sprzętem szpitalnym, np.: fotelami na kółkach, pompami, monitorami, respiratorami, łóżkami itp. Robot HOMER identyfikuje obiekty poprzez odczyt etykiet RFID, w międzyczasie robot TUG roznosi sprzęt tam, gdzie jest on potrzebny lub odkłada z powrotem na swoje miejsce [4].

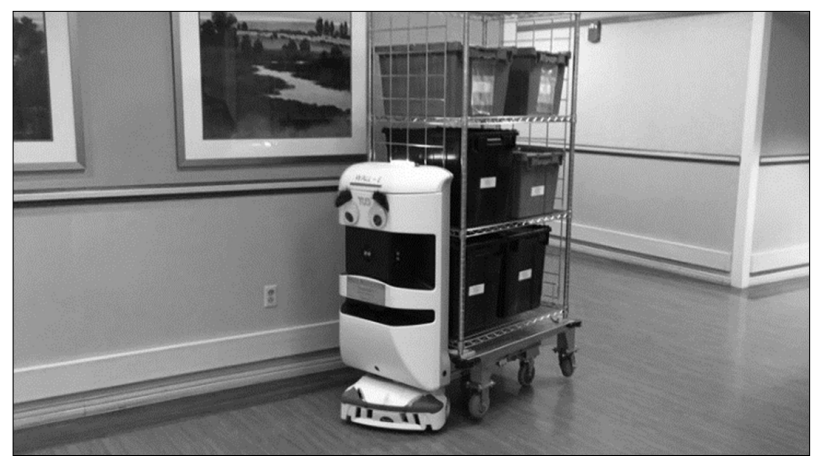

Fot 1. Robot TUG

Źródło: https://www.businesswire.com/news/home/ 20150519005310/en/St.-Elizabeth-Healthcare-Enters-Robotic-Age-TUG /dostęp 12.07.2019/

Innym przykładem robota służącego do wykonywania monotonnych zadań jest robot SpeciMinder, autorstwa firmy CCS Robotics. Zbiera on po salach próbki do badań laboratoryjnych i dostarcza je do laboratorium. Podobnie jak robot TUG do nawigacji wykorzystuje mapę budynku i współpracuje z użytkownikiem. Posiada zabezpieczenia w postaci czytnika kart, by nikt nieupoważniony nie miał dostępu do próbek. Robot SpeciMinder samodzielnie rozpoznaje stan naładowania baterii. W przypadku niskiego stanu naładowania baterii podjeżdża do specjalnej stacji dokującej i ładuje baterie $[7,8,9]$.

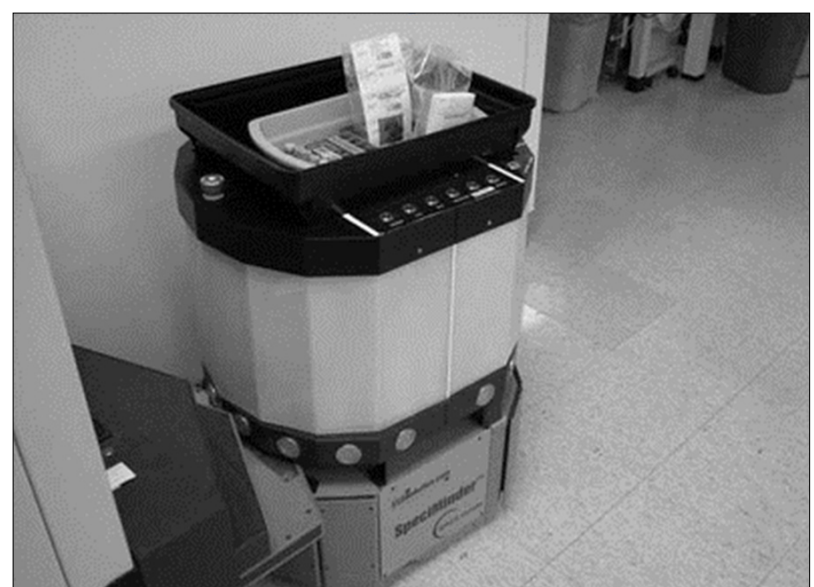

Fot 2. Robot SpeciMinder

Źródło: http://www.ccsrobotics.com/products/speciminder.html /dostęp 12.07.2019/

\section{Wykorzystanie robotów do wykonywania inwazyjnych czynności}

Kolejnym wykorzystaniem nowoczesnych technologii do automatyzacji zadań jest praca robota Bloodbot. Został on stworzony przez Alexa Zivanovica z Imperial College w Londynie. Jest on w stanie autonomicznie wyszukiwać naczynia krwionośnie i wykonywać nakłucia z dokładnością do $1 \mathrm{~mm}$, przy czym warto zauważyć, że jest w stanie rozróżnić mięśnie, tkankę tłuszczową i przede wszystkim naczynia krwionośne. Ponadto, robot Bloodbot jest wyposażony w system przeciwdziałający przebijaniu żył na wylot. Posiada czujnik siły za pomocą którego określa się moment wbijania igły w żyłę - stawiany jest wtedy maksymalny opór, a następnie następuje szybki spadek nacisku - igła znajduje się w naczyniu krwionośnym. Przy spadku nacisku urządzenie natychmiast zatrzymuje dalszy ruch igły. Bloodbot oprócz pobierania krwi do badań potrafi wykonać iniekcję dożylną [10].

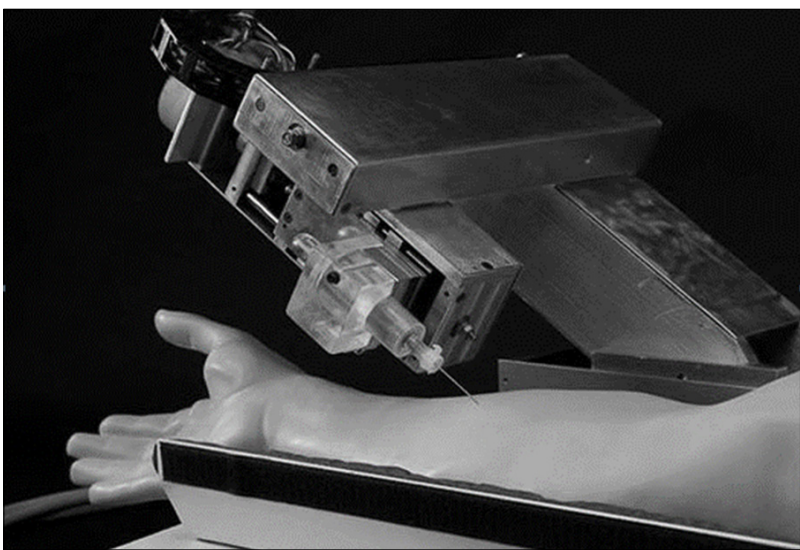

\section{Fot 3. Robot Bloodbot}

Źródło: http://www.asimo.pl/modele/bloodbot.php /dostęp 12.07.2019/

Narzędziem pomocnym w procesie pobierania krwi jest także skaner żył (bezkontaktowy iluminator naczyniowy/naczyń krwionośnych). Skaner żył może być użyteczny przy zakładaniu wkucia obwodowego (venfonu) lub przy pobieraniu krwi od tzw. pacjentów trudnych m.in.: noworodków, starszych pacjentów, pacjentów otyłych, pacjentów z chorobami skóry czy posiadających ciemną karnację. Jest to przenośne urządzenie $(<500 \mathrm{~g})$ umożliwiające lokalizację żył powierzchniowych. Skaner żył działa na zasadzie emitowania światła podczerwonego i niewidzialnego promieniowania laserowego, które wykorzystywane jest do wykrywania żył oraz podświetlenia ich położenia na skórze. Efekt ten uzyskujemy dzięki wchłanianiu promieniowania podczerwonego przez hemoglobinę we krwi [11,12].

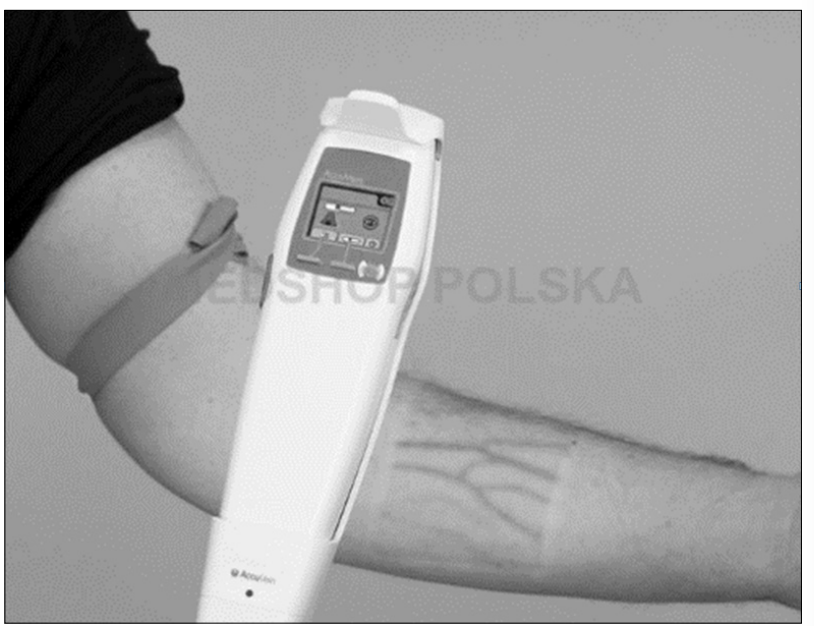

Fot 4. Bezkontaktowy iluminator naczyniowy AccuVein AV400 skaner żył

Źródło: https://medshop.pl/bezkontaktowy-iluminator-naczyniowy-accuvein-av400.html /dostęp 13.07.2019/ 


\section{„Pielęgniarka” Clara jako przykład robota wykonującego nieinwazyjne czynności}

Mechatroniczna pielęgniarka Clara jest skonstruowana przez naukowców z USC Interaction Lab. Robot ten został nazwany na cześć Clary Barton - założycielki Amerykańskiego Czerwonego Krzyża. Robot Clara przemieszcza się wcześniej wyznaczonymi trasami pomiędzy łóżkami chorych, jednakże potrafi wykrywać i omijać przeszkody. Clara jest asystentem dla personelu pielęgniarskiego. Docelowo jej zadaniem jest wyręczać pielęgniarki w prostych czynnościach diagnostycznych, np.: wykonuje pomiar ciśnienia krwi czy badania spirometryczne. Identyfikuje pacjentów skanując kod umieszczony na łóżku danego chorego. Robot Clara posiada ekran na którym wyświetlają się instrukcje dotyczące ćwiczeń. Potrafi komunikować się z pacjentem, odpowiadając na pytania twierdząco lub przecząco. Aizu Central Hospital (Japonia) posiada dwa takie roboty. Jeden $\mathrm{z}$ nich pracuje $\mathrm{w}$ rejestracji, gdzie odpowiada na pytania pacjentów, drugi zaś odprowadza pacjentów do odpowiedniej sali oraz niesie jego bagaż [13].

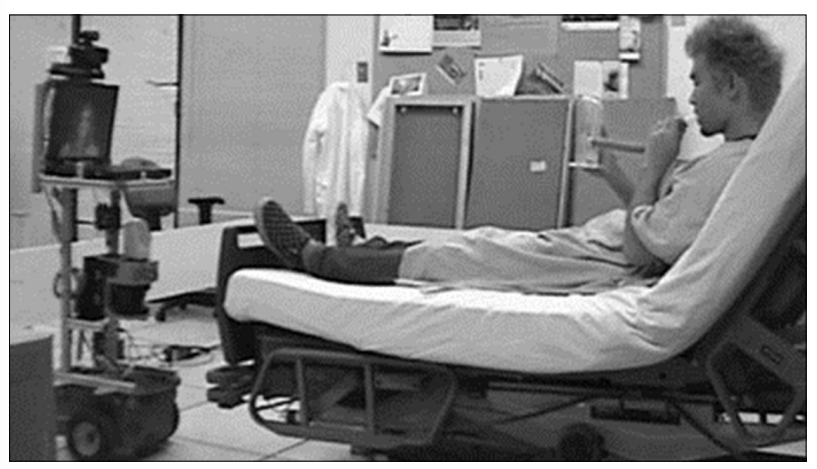

Fig 5. Clara Robot

Źródło: http://www.asimo.pl/modele/clara.php /dostęp 12.07.2019/

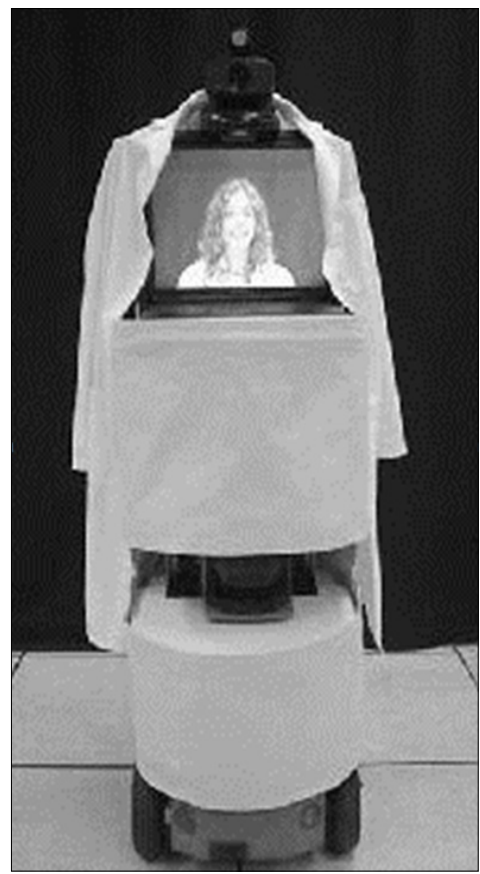

Fig 6. Clara Robot

Źródło: http://www.asimo.pl/modele/clara.php /dostęp 12.07.2019/

\section{Puszysta foka - robotyczna terapia zwierzęca}

Dotychczasowe zastosowania wyręczały pielęgniarki w zadaniach rutynowych, nierzadko żmudnych i powtarzalnych. Nie wyczerpuje to jednakże zakresu pomocy jaki oferują rozwiązania technologiczne. Inną grupę robotów stanowią tak zwane roboty mentalne. Ich główną rolą jest wywoływanie pożądanych efektów psychicznych, takich jak przyjemność czy relaks, a podstawowym „medium” jest komunikacja niewerbalna. Istotną gałąź badawczą stanowi tutaj przeniesienie efektów terapii z wykorzystaniem zwierząt do środków bezpieczniejszych, uniwersalnych i możliwych do zastosowania wobec szerokiego grona pacjentów. Dostrzeżono bowiem, że terapia $\mathrm{z}$ udziałem zwierząt przynosi poprawę w trzech obszarach: psychologicznym (relaksacja), fizjologicznym (obniżenie poziomu stresu, poprawa parametrów życiowych), a także społecznym poprzez stymulację komunikacji pomiędzy pacjentami, opiekunami. Przy czym, zwraca się uwagę, że nie zawsze terapia $\mathrm{z}$ udziałem zwierząt jest możliwa - czy to $z$ powodu przenoszonych przez zwierzęta bakterie, ryzyko zadrapań, czy też powodowania reakcji alergicznych.

Mając na uwadze wymierne korzyści wynikające $z$ terapii z udziałem zwierząt, postanowiono stworzyć interaktywnego robota - zwierzęcia [14]. Na etapie projektowania takiego robota przyjęto trzy kategorie: znajome zwierzęta (np.: pies, kot), nieznajome zwierzęta (np.: foka) i wymyślone/abstrakcyjne zwierzęta. Opracowane prototypy przedstawiono badanym. Problematyczne były różnice percypowane przez badanych przy kontakcie ze zwierzętami znajomymi - przykładowo koty były zbyt miękkie i za mało naturalne $[14,16]$. Z kolei zwierzęta zmyślone nie aktywowały badanych w pożądany sposób. Niejako kompromisem okazały się foki, gdyż uczestnicy badania nie posiadali rozległej wiedzy o zachowaniu i zwyczajach fok, więc nie byli w stanie porównać robota ze zwierzęciem. Badania zostały przeprowadzone w siedmiu krajach: Japonii, Wielkiej Brytanii, Włoszech, Szwecji, Korei, USA i Brunei, co pozwala przypuszczać, iż robot foka może być powszechnie akceptowany, pomimo różnic kulturowych i religijnych [15,16,17].

Robot Paro został zaprojektowany do terapii. Jest to prawie trzykilogramowa $(2,7 \mathrm{~kg})$ foka, mierząca $57 \mathrm{~cm}$. Posiada 340 czujników i 5 sensorów: słuchu, dotyku, światła, temperatury i postawy, a także antybakteryjną sierść odporną na brud, która nie wypada [18]. Wyposażony jest w płytkę elektromagnetyczną, by nie oddziaływać na pacjentów z rozrusznikiem serca $[14,15]$. Robot Paro nastawiony jest na interakcję, wychwytuje obecność człowieka w pobliżu, dzięki obecności czujników. Zaczyna wtedy ruszać się, popiskiwać, domaga się głaskania. Reaguje na czynności tj.: podczas głaskania mruży oczy i mruczy, bity skowycze. Potrafi przekrzywić głowę w stronę z której przebiega dźwięk. Charakter robota Paro może się zmienić w zależności od sposobu traktowania: gdy jest często bity staje się antyspołeczny i piszczy podczas głaskania. Odwrotnie, gdy traktuje się go dobrze jest towarzyski i przyjazny $[14,15,19]$.

Robot Paro posiada pozytywny wpływ na osoby starsze, pacjentów $z$ otępieniem, które w znacznym stopniu ograniczyły swoje możliwości komunikacji i dzieci na oddziałach pediatrycznych oraz osoby z niepełnosprawnością. 
„Foka wymusza interakcje i wzmaga instynkty opiekuńcze tak mocno, ze chorzy zaczynaja się nia opiekować. To ich relaksuje i jednocześnie pobudza, łagodzi napięcie emocjonalne i sprawia radość. Głaskanie miękkiego futerka powoduje wydzielanie się endorfin, czyli naturalnych substancji przeciwbólowych i obniżenie poziomu kortyzolu i noradrenaliny" [18]. W Danii wprowadzono 1000 robotów do placówek związanych z opieką nad osobami starszymi [20]. W Polsce pierwsza foka Paro zamieszkała w Sopockim Domu Opieki Społecznej (DPS) [14,21], kolejna przy Polskim Stowarzyszeniu na Rzecz Osób z Niepełnosprawnością Intelektualną w Skarszewach [22].

Anna Rzeczyńska, terapeutka w sopockim DPS wspomina: „Była u nas taka pani, która nie komunikowała się już $z$ otoczeniem $w$ żaden sposób. Żyła $w$ swoim świecie. Kiedy przystapiliśmy do terapii foka, nie dała znaku, $\dot{z}$ e nie chce, wydawała się ożywiona, więc delikatnie położyłam jej fokę na kolanach. I wtedy zaczęła płakać. I nie były to łzy smutku, tylko wzruszenia, takiej ulgi. Jakby coś w niej drgnęło, jakiś bezpiecznik puścil' [18]. Robot Paro staje się swoistym mediatorem pomiędzy opiekunem a pacjentem. Jest wspólnym tematem i zachęca do komunikacji [15].

Terapia $\mathrm{z}$ wykorzystywaniem robotów zwierzęcych to rozwijająca się dziedzina. Badania wykazały, iż Robot Paro ma ogromny potencjał w zakresie opieki psychiatrycznej nad osobami starszymi. Jednak potrzebne są dalsze badania w tej dziedzinie.

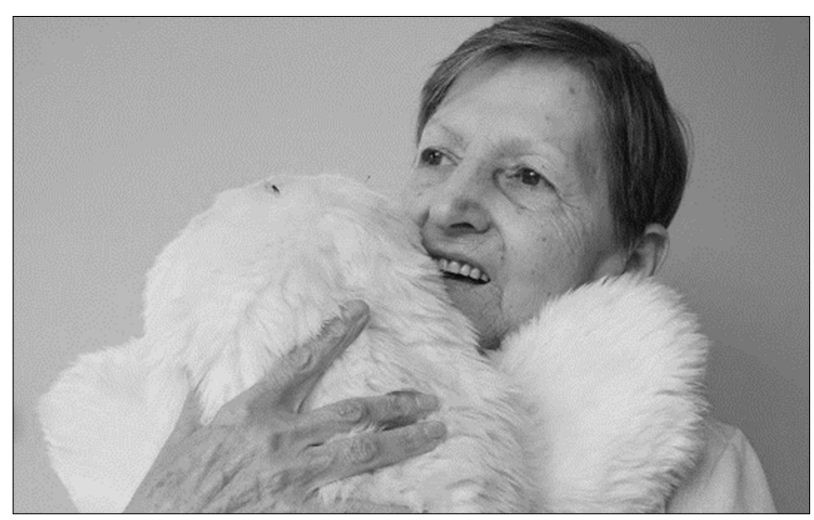

\section{Fot 7. Robot Paro}

Źródło: https://www.sztucznainteligencja.org.pl/foka-alzheimera/ /dostęp 14.07.2019/

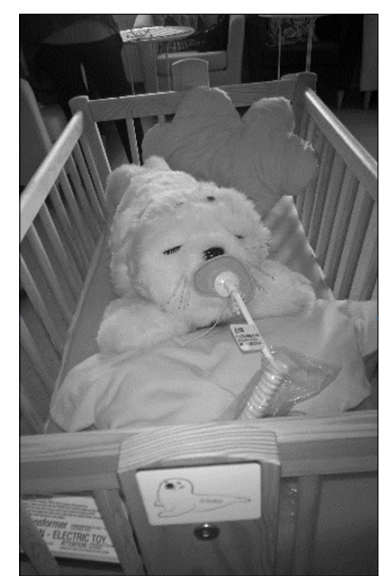

Fig 8. Paro's seal during charging

\section{PODSUMOWANIE}

Bycie pielęgniarką to bardzo wymagająca, ale satysfakcjonująca praca, umożliwiająca „dotknięcie” życia wielu ludzi. Empatia i opiekuńczość nigdy nie zostaną zastąpione przez technologię. Jednak innowacje mogą uwolnić pielęgniarki od ciężaru wielu monotonnych i powtarzalnych zadań [23].

W kontekście współczesnej praktyki pielęgniarskiej pojawiają się takie głosy jak J.A. Pepita i R. Locsina, którzy twierdzą, że obecnie proces pielęgnowania jest często prowadzony w wysoce powtarzalny sposób, określają go wręcz „rutynowym procesem”. W ich opinii te rutynowe zadania powinny zastąpić roboty. Co więcej, uważają oni, iż zawód pielęgniarki może być zagrożony w przypadku zbudowania i wprowadzenia na rynek usług medycznych robota, który będzie naśladował ruchy człowieka, dysponował sztuczną inteligencją, zdolną do podejmowania decyzji klinicznych [24].

Trudno się zgodzić z takim podejściem, gdyż pielęgniarka musi poznać stan bio-psycho-społeczny pacjenta przed ustaleniem procesu pielęgnowania. Roboty mogą go ułatwić czy usprawnić, np.: mierząc parametry życiowe, jednakże nie są w stanie zastąpić pielęgniarek, które mogą zapewniać holistyczną opiekę. Należy pamiętać, że obecnie istnieje znaczny niedobór kadry pielęgniarskiej na całym świecie. Rosnąca ilość pacjentów przy stałym niedostatku pielęgniarek doprowadza do zwiększonej ilości zakażeń czy śmiertelności pacjentów, szybszego wypalenia zawodowego, braku wystarczającego czasu na kontakt $\mathrm{z}$ pacjentem. Roboty są $\mathrm{w}$ stanie odciążyć pracę pielęgniarek w najbardziej monotonnych czynnościach, oszczędzając czas i energię, które mogą zostać przeznaczone na kontakt z pacjentem. Ponadto należy zwróć uwagę, że system opieki nie jest bynajmniej statyczny i wymaga ciągłego udoskonalania procesów. Ostatecznie, naszym celem jest poprawa wyników zdrowotnych, a jednocześnie utrzymanie kontroli nad wzrostem wydatków.

\section{REFERENCES/PIŚMIENNICTWO}

1. Glauser W. Artificial intelligence, automation and the future of nursing. 2017 https://www.canadian-nurse.com/en/articles/issues/2017/may-june-2017/ artificial-intelligence-automation-and-the-future-of-nursing /dostęp 12.07.2019/

2. http://www.egospodarka.pl/145423,Roboty-w-medycynie-Czy-automatyzacjazagraza-lekarzom,1,39,1.html/dostęp 12.07.2019/

3. https://infoplanet.pl/pl/news/portal/polska/technologia-spolecznosc/ technologia-robot-nowym-przyjacielem-czlowieka//dostęp 12.07.2019/

4. http://www.asimo.pl/modele/tug.php/dostęp 12.07.2019/

5. https://www.businesswire.com/news/home/20150519005310/en/St.-ElizabethHealthcare-Enters-Robotic-Age-TUG /dostęp 12.07.2019/

6. https://www.youtube.com/watch?v=eH2OfeRkInE /dostęp 11.07.2019/

7. http://www.asimo.pl/modele/speciminder.php/dostęp 12.07.2019/

8. http://www.egospodarka.pl/145423,Roboty-w-medycynie-Czy-automatyzacjazagraza-lekarzom,1,39,1.html/dostęp 10.07.2019/

9. http://www.ccsrobotics.com/products/speciminder.html/dostęp 12.07.2019/

10. http://www.asimo.pl/modele/bloodbot.php/dostęp 13.07.2019/

11. https://medshop.pl/bezkontaktowy-iluminator-naczyniowy-accuvein-av400.html /dostęp 13.07.2019/

12. https://eresmedical.com.pl/skaner-zyl-vs400-p-571.html/dostęp 12.07.2019/

13. http://www.asimo.pl/modele/clara.php /dostęp 12.07.2019/

14. http://neuropsychologia.org/foka-paro-gdy-robot-staje-się-terapeutą/dostęp 12.07.2019/

Źródło: https://www.facebook.com/pages/category/Health-Beauty/Foka- 


\section{The role of robots in the improving work of nurses}

15. Shibata T, Wada K. Robot Therapy: A New Approach for Mental Healthcare of the Elderly -A Mini-Review. Gerontology. 2011; 57:378-386.

16. Shibata T, Mitsui T, Wada K, Tanie K. Subjective evaluation of seal robot, Paro tabulation and analysis of questionnaire results. J Robot Mechatron. 2002;14:13-19.

17. Shibata T, Wada K, Ikeda Y, Sabanovic S: Cross-cultural studies on subjective evaluation of seal robot. Adv Robot. 2009;27:443-458.

18. https://www.sztucznainteligencja.org.pl/foka-alzheimera//dostęp 14.07.2019/

19. http://www.asimo.pl/modele/paro.php /dostęp 14.07.2019/

20. https://www.bbvaopenmind.com/en/articles/life-innovation-with-therapeuticrobot-paro/ dostęp 13.07.2019/

21. http://dpssopot.pl/2016/04/prezentacja-terapeutycznego-robota-mlodej-fokiparo//dostęp 14.07.2019/

22. http://www.psoni-skarszewy.pl/index.php/orew-wydarzenia/652-foka-paro /dostęp 14.07.2019/

23. https://medicalfuturist.com/the-future-of-nurses-superheros-aided-bytechnology /dostęp 14.07.2019/

24. Pepito JA, Locsin R. Can nurses remain relevant in a technologically advanced future? IJNSS. 2019; 6(1): 106-110.
Manuscript received/Praca zgłoszona do czasopisma: 15.07.2019

Manuscript accepted/Praca zaakceptowana do druku: 31.08.2019

Translation/Tłumaczenie: Łukasz Blechar 